\title{
PROBLEMATIKA PENGUJIAN PERATURAN PERUNDANG-UNDANGAN (JUDICIAL REVIEM) PADA MAHKAMAH AGUNG DAN MAHKAMAH KONSTITUSI
}

\author{
Achmad, Mulyanto \\ Fakultas Hukum Universitas Sebelas Maret \\ achmad1saja@gmail.com \\ sheemoel@yahoo.com
}

\begin{abstract}
The aim of this research is to determine the judicial review problems by Supreme Court and Constitutional court. Using empirical and normative approach, data collected by literature studies, interviews, Focus Group Discussion (FGD) and observation. Data were analyzed by using the hermeneutics (interpretation) and deductive method.

This research reveals that the legal framework of judicial review by Supreme Court and Constitutional Court are the Article 24 A paragraph (1) and Article 24 paragraph C (1) Indonesia basic law 1945. Constitutional court follow up the legal framework by issued PMK No. 06/PMK/2005 on guidelines of the judicial review procedure, while supreme court follow up the legal framework by issued supreme court regulation No 1/ 2011

There are two problems on judicial review by supreme court and constitutional coourt. First, conceptually, the implementation of judicial review by supreme court and constitutional court will make hard the control of norms herarchy in the manner of constitution enforcement.

Second, operationally, the implementation of a judicial review by Supreme Court and the constitutional Court will create a conflict between state body due to the disparities on the verdict and regulation interpretation they have dealt with.
\end{abstract}

Keywords: Judicial Review, Supreme Court, Constitutional court

\section{ABSTRAK}

Penelitian ini bertujuan mengetahui problematika pengujian peraturan perundang-undangan oleh Mahkamah Agung dan Mahkamah Konstitusi. Penelitian ini menggunakan pendekatan normatif sekaligus empiris. Pengumpulan data melalui Studi kepustakaan, Wawancara, Focus Group Discussion (FGD) dan Observasi. Data dianalisis dengan menggunakan metode hermeneutik (interpretasi) di samping deduktif. Hasil penelitian menunjukkan Pengaturan judicial review oleh Mahkamah Agung dan Mahkamah Konstitusi diatur dalam ketentuan Pasal 24 A ayat (1) dan Pasal 24 C ayat (1) UUD NRI 1945. Pelaksanaannya oleh MK ditindak lanjuti melalui PMK No 06/PMK/2005 tentang Pedoman Beracara dalam Perkara Pengujian Undang-Undang sedangkan oleh MA ditindaklanjuti melalui Peraturan Mahkamah Agung No. 1 Tahun 2011. Problematika judicial review melalui Mahkamah Agung dan Mahkamah Konstitusi, Pertama, secara konseptual pelaksanaan pengujian peraturan perundang-undangan ditangan MA dan MK akan menyulitkan integrasi pengawalan hirarki norma mulai dari perda sampai UUD dalam rangka penegakkan konstitusi. Kedua, secara operasional pelaksanaan judicial review antara MA dan MK akan menimbulkan konflik antar lembaga diakibatkan dari perbedaan putusan atau penafsiran peraturan perundang-undangan yang ditangani.

Kata kunci: Pengujian peraturan perundangan, Mhkamah Agung, Mahkamah Konstitusi

\section{A. Pendahuluan}

Banyak keluhan sebelum perubahan UUD 1945 bahwa terdapat peraturan perundangundangan yang bertentangan dengan konstitusi. Sebelum adanya amandemen UUD 1945 tahun 1999-2002, kekuasaan kehakiman tidak diberikan kewenangan melakukan pengujian Undang-Undang terhadap UUD 1945. Dalam perkembangannya sebelum amandemen akhirnya Mahkamah Agung Republik Indonesia (MA RI) sebagai kekuasaan kehakiman diberikan kewenangan melakukan judicial review sebatas peraturan perundang-undangan di bawah Undang-Undang.

Sejak diatur dalam Pasal 26 UU No. 14 Tahun 1970, Pasal 31 UU No. 14 Tahun 1985, dan Pasal 11 Ketetapan MPR No. III/MPR/1978, pelaksanaan perkara pengujian peraturan di bawah UndangUndang terhadap Undang-Undang ternyata belum dapat berjalan sebagaimana mestinya, bahkan selama 22 tahun tidak ada perkara 
pengujian peraturan. Perkara pengujian melalui proses proses gugatan mulai diajukan ke MA RI, sejak tahun 1993 sebanyak dua perkara, dan sampai dengan tahun 1998 perkara pengujian yang teregistrasi sebanyak 10 perkara dan yang telah diputus sebanyak lima perkara atau $50 \%$, dan sisanya lima perkara masih dalam proses pemeriksaaan di mahkamah Agung (Zainal Arifin Hoesein,2009 : 207).

Situasi politik dan hukum mulai berubah saat terjadi reformasi tahun 1997/1998. Momentum reformasi digunakan untuk melakukan reformulasi sistem ketatanegaraan melalui amandemen UUD 1945 tahun 1999-2002. Dalam proses amandemen tersebut, salah satu isu yang menjadi perdebatan adalah upaya diberikannya kewenangan lembaga yudisial untuk melakukan pengujian peraturan perundang-undangan setingkat UU terhadap UUD. Waktu itu perdebatan terbelah menjadi tiga kelompok, yaitu pertama, kelompok yang menghendaki kewenangan pengujian UU terhadap UUD diberikan kepada MA, kedua, kelompok yang menghendaki pengujian diberikan kepada lembaga yudisial diluar MA yaitu Mahkamah Konstitusi dan kelompok ketiga adalah kewenangan pengujian UU terhadap UUD diberikan kepada MPR atau sering disebut legislatif review.

Dalam putusannya, akhirnya Amandemen UUD 1945 (1999-2002) merumuskan ada dua lembaga kekuasaan kehakiman (Mahkamah Konstitusi dan Mahkamah Agung) yang diberi kewenangan untuk melakukan judicial review. MA tetap diberikan kewenangan melakukan pengujian peraturan perundang-undangan di bawah undangundang dan kewenangan pengujian undang-undang terhadap UUD diberikan kepada Mahkamah Konstitusi. Pembedaan pemberian kewenangan pengujian peraturan perundang-undangan kepada dua lembaga yang berbeda akan menimbulkan problematika tersendiri dalam praktik ketatanegaraan Indonesia pasca Amandemen UUD 1945 (1999-2002).

\section{B. Tinjauan Pustaka}

\section{Pengujian Peraturan Perundang- Undangan}

Konsep judicial review berasal dari negaranegara yang menganut prinsip supremasi konstitusi. Istilah judicial review itu sendiri merupakan istilah khas hukum tata negara Amerika Serikat yang artinya wewenang lembaga pengadilan untuk membatalkan setiap tindakan pemerintahan yang bertentangan dengan konstitusi. Menurut Soepomo, di Belanda tidak dikenal istilah judicial review, mereka hanya mengenal istilah hak menguji (toetsingensrecht). Judicial review merupakan mekanisme pengujian peraturan perundangundangan tertentu oleh hakim. Pengujian itu dilakukan atas suatu ketentuan peraturan perundang-undangan terhadap peraturan perundang-undangan yang lebih tinggi atau terhadap konstitusi sebagai hukum tertinggi. (Moh. Mahfud MD, 2009 : 8)

Sejarah panjang mengenai pengujian produk legislasi oleh sebuah lembaga peradilan (judicial review) akan terus berkembang. Bermula dari Amerika (1803) dalam perkara Madison versus Marbury hingga pembentukan peradilan khusus konstitusional di Austria (1920). Pokok-pokok pemikiran John Marshall dan Hans Kelsen telah mempengaruhi "cara" berhukum di banyak negara. Indonesia sendiri kemudian mengimplementasikan konsep tersebut pada perubahan UUD ketiga. Mahkamah Konstitusi Republik Indonesia (MK)

Lee Bridges, George Meszaros dan Maurice Sunkin mengemukakan, "judicial review has been increasingly celebrated, not least by the judiciary itself, as means by which the citizen can obtain redress against oppressive government, and as a key vehicle forenabling the judiciary to prevent and checks theabuse of executive power". Keberadaan sistem pengujian konstitusional memang terus berkembang di seantero dunia. Mekanisme ini diterima sebagai cara Negara hukum modern untuk mengendalikan dan mengimbangi (check and balances) kecenderungan kekuasaan sewenang-wenang). (Jimly Asshiddiqie, 2006 :v).

Dalam pelaksanaan kadang istilah judicial review dipersamakan dengan constutisional review. Dalam bukunya Jimly mengingatkan perbedaannya. Judicial review lebih luas dari constitutional review karena objek yang diujinya tidak hanya mengenai produk hukum berbentuk undang-undang, tetapi mencakup pula peraturan perundang-undangan di bawah undang-undang. Akan tetapi judicial review dapat pula mencakup pengertian yang lebih sempit karena subjek yang mengujinya hanya hakim atau lembaga judisial, sedangkan constitutional review bisa lebih luas tergantung lembaga mana yang diberi kewenangan oleh Undang-Undang Dasar suatu negara. (Jimly Asshiddiqie, $2010: 4$ ).

Problematika Pengujian Peraturan... 


\section{Norma hukum yang diuji}

Dalam praktek, dikenal adanya tiga macam norma hukum yang dapat diuji atau yang biasa disebut sebagai norm control mechanism. Ketiganya sama-sama merupakan bentuk norma hukum sebagai hasil dari proses pengambilan keputusan hukum, yaitu: (i) keputusan normatif yang berisi dan bersifat pengaturan ( regeling), (ii) keputusan normatif yang berisi dan bersifat penetapan administratif (beschikking), dan (iii) keputusan normatif yang berisi dan bersifat peng hakiman (judgement) yang biasa disebut vonis. (Jimly Asshiddiqie, 2006 : 1).

Ketiga bentuk norma hukum tersebut di atas sama-sama dapat diuji kebenarannya melalui mekanisme peradilan (justisial) ataupun mekanisme nonjustisial. Jika pengujian itu dilakukan oleh lembaga peradilan, maka proses pengujiannya itu disebut sebagai judicial review atau pengujian oleh lembaga judisial atau pengadilan. Akan tetapi, jika pengujian itu dilakukan bukan oleh lembaga peradilan, maka hal itu tidak dapat disebut sebagai judicial review.

Judicial review adalah pengujian oleh lembaga yudikaif tentang konsistensi UU terhadap UUD atau peraturan perundangundangan terhadap peraturan perundangundangan yang lebih tinggi. (Moh. Mahfud, 2010 : 372) Irham In Campus/SEMESTER III/ HUKUM POLITIK DAN KETATANEGARAAN/ SEJARAH PERKEMBANGAN JUDICIAL REVIEW DI INDONESA.docX - ftn3

Pasca amandemen UUD telah terjadi pergeseran sistem ketatanegaraan dan penyelenggaraan negara, dengan tidak ada lagi lembaga yang supreme yang sebelumnya diperankan MPR serta adanya penegasan pemisahan kekuasaan dan prinsip checks and balances.

Kehadiran Mahkamah konstitusi dalam sistem ketatanegaraan tidak lain berperan sebagai pengawal konstitusi (the guardian of the constitution), agar konstitusi selalu dijadikan landasan dan dijalankan secara konsisten oleh setiap komponen negara dan masyarakat. MK berfungsi mengawal dan menjaga agar konstitusi ditaati dan dilaksanakan secara konsisten, serta mendorong dan mengarahkan proses demokratisasi berdasarkan konstitusi. (Cetak biru Membangun Mahkamah Konstitusi Sebagai Institusi Peradilan Konstitusi yang Modern dan Terpercaya, 2004 : 45-46).

\section{Metode Penelitian}

Penelitian ilmu hukum ini menggunakan pendekatan secara normatif sekaligus empiris. Dalam ranah penelitian hukum di Indonesia, konsep penelitian ilmu hukum termasuk yang masih dianggap baru

Dalam hal penelitian hukum ini dipergunakan beberapa pendekatan, yaitu pendekatan peraturan perundang-undangan (statute approach), pendekatan kasus (case approach), (Peter Mahmud Marzuki, 2007 : 93). Penelitian ini meskipun hendak mengungkap ide, konsep, dan solusi serta struktur, institusi, dan metode dalam sistem hukum yang bertemu, namun tetap bertolak dari hal ikhwal normatif.

Data dikumpulkan dengan menggunakan instrumen antara lain : Studi kepustakaan, Wawancara, Focus Group Discussion (FGD) dan Observasi. Untuk penelitian hukum, bahan hukum dianalisis dengan menggunakan metode hermeneutik (interpretasi) disamping deduktif. Untuk penelitian sosio legal, data dianalisis secara kualitatif lewat pengayaan internal untuk memperoleh gambaran pemahaman yang lengkap (verstehen).

\section{Hasil Penelitian dan Pembahasan}

1. Identifikasi Pengaturan Judicial Review di Mahkamah Agung dan mahkamah Konstitusi

a. Pengaturan Judicial Review di Mahkamah Agung

Kewenangan Mahkamah Agung dalam melaksanakan Hak Uji Materiil (HUM) pada mulanya didasarkan pada landasan hukum Pasal 24 UUD 1945 sebagaimana telah diamandemen menjadi Pasal 24 A UUD Negara Republik Indonesia. Pasal 26 UU No. 14 Tahun 1970 tentang Ketentuan Pokok Kekuasaan Kehakiman; Pasal 11 ayat (4) Ketetapan MPR No. III/ MPR/1978 tentang Kedudukan dan Hubungan Tatakerja Lembaga Tertinggi Negara dengan/atau Antar Lembaga Tinggi Negara; Pasal 31 UU No. 14 Tahun 1985 tentang Mahkamah Agung. Pasal $11 \mathrm{UU}$ No. 4 Tahun 2004 tentang Kekuasaan Kehakiman Pasal 20 UU No 48 Tahun 2009 tentang Kekuasaan Kehakiman.

Menurut Paulus Effendi Lotulung, bahwa alasan prosedur hak uji materiil (HUM) dibuat dalam bentuk hukum PERMA didasarkan pada pertimbangan ketentuan Undang-undang yang memberikan kewenangan HUM tersebut hanya bersifat singkat saja tanpa mengatur tentang tata cara atau prosedur

Problematika Pengujian Peraturan... 
pelaksanaan HUM. Oleh karena itu, untuk mengisi kekosongan hukum agar tidak terjadi vakum yang akhirnya merugikan pencari keadilan, maka ditempuhlah cara melalui pembuatan PERMA Yang didasarkan pada kewenangan MA berdasar Pasal 79 UU No. 14 Tahun 1985. Adapun Pasal 79 berbunyi, "Mahkamah Agung dapat mengatur lebih lanjut hal-hal yang diperlukan bagi kelancaran penyelenggaraan peradilan apabila terdapat hal-hal yang belum cukup diatur dalam Undang-undang ini". Dengan demikian inisiasi MA menyusun PERMA adalah untuk sementara sambil menunggu dikeluarkannya Undang-undang yang mengatur prosedural HUM.

Sejak MA diberikan kewenangan untuk melakukan hak uji materiil hingga sekarang mahkamah agung telah membentuk lima kali perubahan peraturan mahkamah agung tentang tata cara hak uji materiil yaitu Perma No 1 tahun 1993, Perma No. 1 Tahun 1999, Perma No. 2 Tahun 2002, Perma No. 1 Tahun 2004 dan terakhir diubah melalui Perm No. 1 tahun 2011. Ada perubahan yang diatur dalam Perma No. 1 Tahun 2011, yaitu mengenai tenggang waktu pengajuan HUM yang semula dibatasi 180 hari (Perma No 1 Tahun 2004) dihapuskan. Hal tersebut dilakukan berdasar masukan dan aspirasi dari berbagai kalangan akademisi maupun praktisi demi perbaikan sistem HUM. Selain itu juga memberikan kesempatan yang lebih luas bagi pencari keadilan sebab ketika ada pembatasan tenggang waktu berimplikasi pada banyaknya perkara yang tidak dapat diterima karena melebihi batas waktu yang telah ditetapkab. Peraturan ini merupakan langkah maju dari MA (Wawancara dengan Bp Ashadi, SH, Panitera Muda Tata Usaha Negara (TUN) Mahkamah Agung, 26 September 2012).

b. Pengaturan Judicial Review di Mahkamah Konstitusi

Upaya pembentukan Mahkamah konstitusi adalah salah satu wujud nyata perubahan sistem ketatanegaraan, sehingga tercipta keseimbangan dan kontrol yang ketat di antara lembaga negara. Meskipun demikian, hakikat pembentukan Mahkamah Konstitusi selain lebih mempertegas prinsip negara hukum dan perlindungan hak asasi manusia yang telah dijamin konstitusi, juga sebagai sarana penyelesaian sengketa ketatanegaraan yang memerlukan lembaga atau badan yang berwenang menyelesaikannya, karena sebelumnya tidak ada dalam UUD 1945. (Iriyanto, 2008 : ix)

Mahkamah Konstitusi merupakan salah satu pelaku kekuasaan kehakiman, di samping Mahkamah Agung. Hal ini dirumuskan secara eksplisit dalam ketentuan Pasal 24 ayat (2) UndangUndang Dasar Negara Republik Indonesia Tahun 1945 yang menyebutkan Kekuasaan kehakiman dilakukan oleh sebuah Mahkamah Agung dan badan peradilan yang berada di bawahnya dalam lingkungan peradilan umum, lingkungan peradilan agama, lingkungan peradilan militer, lingkungan peradilan tata usaha negara, dan oleh sebuah Mahkamah Konstitusi.

Lebih lanjut fungsi mahkamah konstitusi dirumuskan dalam ketentuan Pasal 24C ayat (1) dan ayat (2) UndangUndang Dasar Negara Republik Indonesia Tahun 1945 berwenang untuk: (1) menguji undang-undang terhadap UndangUndang Dasar Negara Republik Indonesia Tahun 1945; (2) memutus sengketa kewenangan lembaga negara yang kewenangannya diberikan oleh UndangUndang Dasar Negara Republik Indonesia Tahun 1945; (3) memutus pembubaran partai politik; (4) memutus perselisihan hasil pemilihan umum; dan (5) memberikan putusan atas pendapat DPR bahwa Presiden dan/atau Wakil Presiden diduga telah melakukan pelanggaran hukum berupa pengkhianatan terhadap negara, korupsi, penyuapan, tindak pidana berat lainnya, atau perbuatan tercela, dan/atau tidak lagi memenuhi syarat sebagai Presiden dan/atau Wakil Presiden sebagaimana dimaksud dalam Undang-Undang Dasar Negara Republik Indonesia Tahun 1945.

Berdasarkan ketentuan itulah pengaturan judicial review oleh mahkamah konstitusi mendapatkan pijakan dasar hukumnya. Judicial review yang diatur dalam pasal $24 \mathrm{C}$ ayat (1) hanya membatasi fungsi Mahkamah Konstitusi untuk melakukan judicial review undangundang terhadap UUD Negara Republik Indonesia Tahun 1945. 
Pengaturan mengenai pengujian peraturan perundang-undangan di Mahkamah Konstitusi lebih jelas dirumuskan dalam ketentuan UU No 24 tahun 2003 tentang Mahkmah Konstitusi sebagaimana telah diubah dengan UU No 8 Tahun 2011 tentang Perubahan Atas Undang-Undang Nomor 24 Tahun 2003 Tentang Mahkamah Konstitusi. Pasal 53 menyebutkan bahwa Mahkamah Konstitusi memberitahukan kepada Mahkamah Agung adanya permohonan pengujian undang-undang dalam jangka waktu paling lambat 7 (tujuh) hari kerja sejak permohonan dicatat dalam Buku Registrasi Perkara Konstitusi. Pasal ini sebagai dasar untuk menjalin komunikasi ataupun koordinasi antara dua lembaga kekuasaan kehakiman Mahkamah Agung dan mahkamah Konstitusi dalam menjalankan fungsinya masing-masing.

2. Problematika Pelaksanaan pengujian peraturan perundang-undangan (Judicial Review) di dua lembaga Mahkamah Agung dan Mahkamah Konstitusi

Pemikiran mengenai konsep pengujian peraturan perundang-undangan (judicial review) di Indonesia sebetulnya bukan merupakan sesuatu hal yang baru. Namun, konsep ini mulai berkembang dan menemukan bentuknya dalam tataran hukum serta praktik ketatanegaraan di Indonesia sejak terjadinya Perubahan atas UUD 1945. Sayangnya, pengujian peraturan perundang-undangan dalam desain UUD 1945 dengan memberikan dua lembaga (MA dan MK) untuk melakukan pengujian peraturan perundang-undangan tidaklah kemudian dapat mengakhiri persoalan dan perdebatan yang ada selama ini. Bahkan, justru bertendensi menimbulkan problematika baru baik dalam tataran teoritis maupun dalam artikulasi empirisnya yang sudah barang tentu memicu perdebatan-perdebatan berikutnya. Ada dua problematika mendasar yang dihadapi dalam pelaksanaan pengujian peraturan perundang-undangan (judicial review) yaitu :

a. Problematika konseptual

Di Indonesia ada dua lembaga (MA dan MK) yang diberikan kewenangan untuk melakukan pengujian peraturan perundang-undangan dengan objek pengujian yang berbeda. Mahkamah Agung melakukan pengujian peraturan perundang-undangan di bawah undangundang dan Mahkamah Konstitusi melakukan pengujian undang-undang terhadap Undang-Undang Dasar. Adanya dua lembaga yang berbeda tersebut akan menimbulkan problematika konseptual dalam pelaksanaannya. $\mathrm{Hal}$ ini disebabkan tidak ada lembaga tertinggi untuk mengawal dan menegakkan konstitusi. Teori hirarki norma dan asas pembentukan peraturan perundangundangan tidak sepenuhnya bisa dilakukan diimplementasikan secara integral. Mekanisme pengujian peraturan perundang-undangan di bawah undangundang yang langsung diuji dengan Undang-Undang Dasar Negara Republik Indonesia belum ada pijakan hukumnya.

Berdasarkan kewenangan konstitusional Mahkmah Konstitusi dalam hal menguji konstitusionalitas undangundang, mahkamah konstitusi melalui putusannya dapat menyatakan bahwa materi rumusan dari suatu undang-undang tidak mempunyai kekuatan hukum mengikat karena bertentangan dengan UUD 1945. Begitupun terhadap keberlakuan suatu undang-undang, Mahkamah Konstitusi dapat membatalkan keberlakuannya karena tidak sesuai dan tidak berdasarkan UUD 1945. (Ikhsan Rosyada Parluhutan Daulay, 2006 : 57-58).

Prinsip utamanya, undang-undang pada dasarnya adalah kristalisasi dari kepentingan-kepentingan politik para pembuatnya. Sebagai produk politik, maka patut diduga di dalamnya terdapat muatan kepentingan yang mungkin saja bertentangan atau melanggar kaidahkaidah konstitusi. Sesuai prinsip hierarki hukum, tidak boleh isi suatu peraturan undang-undang yang lebih rendah bertentangan atau tidak mengacu pada peraturan di atasnya. Untuk itu perlu tersedia mekanisme untuk menguji apakah suatu undang-undang bertentangan dengan konstitusi atau tidak (Moh. Mahfud MD, 2009 : 8).

Menurut Maruarar Siahaan pengalaman menunjukkan bahwa ada kalanya peraturan perundang-undangan di bawah undang-undang yang menjadi pusat permasalahannya, bukanlah ketidaksesuaian dengan undang-undang yang menjadi dasar atau landasan pembentukannya, melainkan justru pertentangan atau ketidaksesuaian dengan UUD. Ini merupakan satu kekosongan dan masalah 
tersendiri dalam ketatanegaraan Indonesia, karena uji konstitusionalitas (constitutional review) terhadap peraturan perundang-undangan di bawah UU tersebutlah yang merupakan masalah yang sungguh-sungguh menjadi perhatian (Jimly Asshiddiqie, 2007 : 282).

Di dalam kehidupan bermasyarakat tidak hanya undang-undang saja yang bertentangan dengan UUDNRI Tahun 1945 ataupun hanya pertentangan antara peraturan perundang-undangan dibawah undang-undang terhadap undang-undang. Namun seringkali dijumpai adanya pertentangan antara peraturan perundangundangan dibawah undang dengan konstitusi, Selain itu permasalahan lain adalah adanya 2 lembaga yang berwenang dalam melakukan pengujian materi yang mengakibatkan tidak ada sinkronisasi antar peraturan perundang-undangan dari peraturan perundang-undangan paling bawah sampai dengan yang paling atas.

Secara ideal melalui kewenangan judicial review yang dimilikinya, MK merupakan lembaga negara yang mengawal politik hukum nasional agar tidak lagi terdapat ketentuan hukum yang keluar dari koridor konstitusi. Dengan demikian upaya memperkuat nation building melalui penegakkan konstitusi dapat dilakukan oleh lembaga yudisial dalam hal ini Mahkamah Konstitusi. MK dengan segenap kewenangannya menjadi ikhwal penting bagi ikhtiar mewujudkan konstitusionalitas Indonesia, sehingga patut dan tidaklah berlebihan jika MK disebut sebagai pengawal konstitusi (the guardian of constitution).

Konseptual penataan politik hukum perundang-undangan melalui putusan peradilan untuk memperkuat nation building masih sulit diwujudkan. Hal ini disebabkan secara konseptual belum ada lembaga yang secara integral dan menyeluruh dapat mengawal penegakkan konstitusi untuk mereview seluruh peraturan perundang-undangan mulai tingkat bawah sampai pada lebih tertinggi agar sejalan dengan UUD NRI 1945.

b. Problematika terjadinya konflik kelembagaan

Mahkamah konstitusi dibentuk untuk menjamin agar konstitusi sebagai hukum tertinggi dapat ditegakkan sebagaimana mestinya. Karena itu, Mahkamah Konstitusi biasa disebut sebagai guardian of the constitution. Dalam melakukan fungsi peradilan dalam bidang kewenangannya, Mahkamah Kostitusi melakukan penafsiran terhadap UUD sebagai satu-satunya lembaga yang mempunyai kewenangan tertinggi untuk menafsirkan konstitusi (the sole Interpreter of the Constitution), bahkan dalam rangka kewenangannya untuk memutus perselisihan hasil pemilu, Mahkamah Konstitusi juga dapat disebut sebagai pengawal proses demokrasi (the guardian of the process of democratization) (Jimly Asshiddiqie, 2006. 103-105).

Di samping itu dalam konstitusi negara modern ditetapkan pula didalamnya hak-hak warga negara, dan oleh karena hak-hak tersebut tercantum dalam konstitusi maka statusnya menjadi hakhak konstitusi warga negara yang secara substantif harus ditegakkan pula oleh peradilan tata negara, dan oleh sebab itu peradilan tatanegara juga berfungsi sebagai (the guardian of citizens). (Harjono, 2007 : 72).

Pembagian tugas di bidang pengujian peraturan (judicial review) atas peraturan perundang-undangan antara Mahkamah Agung dan Mahkamah Konstitusi sama sekali tidak ideal. Sebab dapat menimbulkan perbedaan atau putusan yang saling bertentangan antara Mahkamah Konstitusi dan Mahkamah Agung (Ni'matul Huda. 2008: 115).

Adanya dualisme kewenangan judicial review oleh dua lembaga Mahkamah Agung dan Mahkamah Konstitusi secara empiris cepat atau lambat akan menimbulkan konflik kelembagaan antara Mahkamah Agung dan Mahkamah Konstitusi. Walaupun secara konseptual potensi ini konflik antar lembaga sudah diminimalisir dengan ketentuan Pasal 55 UU No 24 Tahun 2003 sebagaimana telah diubah dengan UU No 8 Tahun 2011 tentang Mahkamah Konstitusi bahwa Pengujian peraturan perundang-undangan di bawah undang-undang yang sedang dilakukan Mahkamah Agung wajib dihentikan apabila undang-undang yang menjadi dasar pengujian peraturan tersebut sedang dalam proses pengujian Mahkamah Konstitusi sampai ada putusan Mahkamah Konstitusi.

Problematika Pengujian Peraturan... 
Namun demikian rumusan tersebut belum mampu mencegah secara keseluruhan potensi terjadinya konflik antar lembaga. Bagaimana apabila pengujian materi dibawah undang-undang telah diuji lebih dahulu oleh MA kemudian karena ada pihak yang tidak puas terhadap putusan MA mengajukan judicial review ke Mahkamah Konstitusi dan putusannya berbeda. Rumusan pasal tersebut belum mampu mencegah terjadinya penafsiran yang berbeda terkait dengan penangan perkara dengan fokus obyek yang sama. Hal ini pernah terjadi pada tahun 2009 terkait dengan perkara metode penghitungan sisa suara pemilihan umum tahun 2009.

Kronologis perkara yakni mulai dari adanya Peraturan Komisi Pemilihan Umum No. 15 Tahun 2009, tanggal 16 Maret 2009 tentang Pedoman Tekhnis Penetapan Dan Pengumuman Hasil Pemilihan Umum, Tata Cara Penetapan Perolehan Kursi, Penetapan Calon Terpilih Dan Penggantian Calon Terpilih Dalam Pemilihan Umum Anggota DPR, DPD, DPRD Provisinsi, Dan DPRD Kabupaten/ Kota Tahun 2009.

Dari pemberlakuan Peraturan KPU No. 15 Tahun 2009 tersebut, Calon Anggota DPR RI dari Partai Demokrat (Zaenal Ma'arif, SH, Yosef B Badeoda, SH.MH., Drs. H.M.Utomo A.Karim T, SH dan Mirda Rasyid, SE.MM.) selaku Partai Politik Peserta Pemilu 2009 merasa kepentingannya dirugikan akibat tidak memperoleh kursi yang menjadi haknya dalam Pemilu 2009. Maka, mereka yang secara yuridis memiliki legal standing mengajukan permohonan HUM kepada MA, mengingat Mengingat Peraturan KPU merupakan termasuk salah satu objek HUM.

Dalam putusan MA No. 15 P/HUM/ 2009 Mahkamah menilai Pasal 22 huruf c dan pasal 23 ayat 1 dan 3 dalam Peraturan itu bertentangan dengan UU Nomor 10 Tahun 2008 tentang Pemilu pasal 205 ayat 4. MA dalam putusan Nomor 15P/HUM/ 2009 meminta KPU membatalkan pasalpasal tentang penetapan calon terpilih pada tahap kedua tersebut. KPU juga diharuskan merevisi Keputusan KPU No 259/Kpts/KPU/Tahun 2009 tentang penetapan perolehan kursi.

Mensikapi putusan MA tersebut ada beberapa pihak (sejumlah Partai Politik) mengajukan gugatan Judicial Review ke
Mahkamah Konstitusi. Perkara Nomor 110/PUU-VII/2009 diajukan Partai Hati Nurani Rakyat (Hanura) yang diwakili oleh H. Wiranto, S.H dan Yus Usman Sumanegara, S.E., MBA. Perkara Nomor 111/PUU-VII/2009, yang diwakili oleh Ahmad Yani, SH, MH, Drs. H. Zainut Tauhid Sa'adi, M. Romahurmuziy, ST, MT, Drs. Machmud Yunus dan H. Muhammad Arwani Thomafi (Partai PPP). Selanjutnya Perkara Nomor 112/PUU-VII/2009, Partai Gerakan Indonesia Raya (Gerindra) yang diwakili oleh Prof. Dr. Ir. Suhardi, M.Sc. dan Ahmad Muzani. Terakhir Perkara Nomor 113/PUU-VII/2009, Partai Keadilan Sejahtera yang diwakili oleh Tifatul Sembiring dan $\mathrm{H}$. M Anis Matta dari Partai Keadilan Sejahtera (PKS).

Dalam amar putusannya, Majelis Hakim Konstitusi yang diketuai oleh Prof Mahmud MD, memutuskan Pasal 205 ayat (4) dan Pasal 212 ayat (3) UU 10/ 2008 adalah konstitusional bersyarat. Artinya, MK mengukuhkan pasal tersebut sepanjang sesuai ketentuan yang ditetapkan MK sekaligus secara tidak langsung mementahkan Putusan MA No. 15 P/HUM/2009 terkait pembatalan penghitungan kursi tahap dua.

Hal yang paling kentara terlihat adalah terjadinya double counting (penghitungan suara ganda) yang berimplikasi pada perolehan kursi Legislatif. Keputusan MA melegalkan terjadinya Double counting dengan mengabaikan makna tersurat BPP (Bilangan Pembagi Pemilih) dalam UU tersebut. MA melegalkan partai-partai yang mendapatkan kursi pada tahap pertama tetap mendapat kursi pada tahap kedua tanpa perlu membandingkan sisa suaranya dengan perolehan suara partaipartai yang suaranya tidak melebihi BPP. Hasil urutan partai pada perhitungan tahap kedua ini sudah pasti sama dengan urutan partai pada perhitungan tahap pertama.

Dengan adanya keputusan MK ini, maka doubel counting tidak terjadi. Sistem proporsional dalam pemilu dapat dicapai maksimum. Deviasi antara perolehan kursi terhadap persentase jumlah suara terjadi sekecil mungkin. Dan dalam hal ini saya sepakat dengan penafsiran MK terhadap frasa "suara" pada Pasal 205 ayat (4) UU $10 / 2008$ dalam ranah sistem pemilu yang proportional, makna "suara" harus dimaknai sebagai: (1) Sisa suara yang diperoleh partai politik setelah 
dipergunakan untuk memenuhi BPP dan (2) Suara yang belum dipergunakan untuk penghitungan kursi sepanjang mencapai $50 \%$ dari BPP. Dengan demikian, melalui putusan MK 110,111,112,113/PUU-VII/ 2009, MK telah memberi kepastian hukum pada Pasal 205, 211, dan 212 UU Nomor $10 / 2008$ yang sarat dengan multitafsir oleh kepentingan pihak-pihak tertentu.

Berdasarkan kasus tersebut secara kasat mata akan dapat diketahui benihbenih konflik kelembagaan antara Mahkamah Agung dengan mahkamah Konstitusi dapat terjadi. Perbedaan penafsiran penghitungan sisa suara pada pemilu tahun 2009 disatu sisi diuji oleh MA terkait dengan Putusan MA No. $15 \mathrm{P} /$ $\mathrm{HUM} / 2009$ dan MA membatalkan beberapa pasal dalam ketentuan Peraturan KPU Nomor 15 Tahun 2009. Kemudian para pihak yang dirugikan mengajukan permohonan judicial review ke mahkamah konstitusi terkait dengan UU yang dijadikan batu uji perkara di MA. Putusan MK memutuskan bahwa pasalpasal UU Nomor 10 tahun 2008 yang diajukan pemohon adalah konstitusional bersyarat. Artinya putusan yang akan dipakai adalah putusan MK. Hal ini disebabkan MK menguji UU terhadap UUD sehingga secara tidak langsung putusan MK akan lebih utama dilaksanakan.

Benturan tersebut terjadi karena terdapat UU yang sama-sama dipergunakan dalam melaksanakan kewenangan judicial review. MK menjadikan UU sebagai objek yang diujikan konstitusionalitasnya terhadap UUD, sedangkan MA menjadikan UU sebagai dasar pengujian terhadap peraturan KPU. Hal ini menyebabkan terjadi konflik secara tidak langsung antara putusan MA dan MK dalam perselisihan penghitungan hasil Pemilu 2009 yang lalu. Kedua lembaga itu samasama ingin menafsirkan ketentuan Pasal 205 ayat (4) Undang-Undang Nomor 10 Tahun 2008 terkait dengan penghitungan tahap kedua untuk penetapan perolehan kursi DPR bagi parpol peserta Pemilu tahun 2009. Dalam kasus tersebut putus0an MK secara tidak langsung menyatakan bahwa putusan MA tidak dapat diberlakukan dikarenakan kehilangan dasar berpijaknya (UU No.10/ 2008).
Kasus pengujian peraturan KPU pada Pemilu 2009 memberikan pembelajaran bahwa begitu berbahaya apabila kewenangan judicial review dimiliki oleh dua institusi peradilan yang berbeda. Karena akan berpotensi terjadinya konflik antar lembaga. Maka perlu di ada gagasan pengintegrasian pengujian peraturan perundang-undangan dalam satu lembaga yudisial agar dapat memperkuat nation building.

\section{E. Simpulan}

1. Dasar hukum Pengaturan judicial review dilakukan oleh dua lembaga kekuasaan kehakiman yaitu di Mahkamah Agung dan Mahkamah Konstitusi diatur dalam ketentuan Pasal 24 A ayat (1) dan Pasal 24 C ayat (1) UUD NRI 1945. UU No 4 Tahun 2004 Tentang Kekuasaan Kehakiman jo UU No 48 Tahun 2009 tentang Kekuasaan Kehakiman. Dalam ranah aplikatif secara prosedural judicial review oleh MK ditindak lanjuti melalui PMK No 06/ PMK/2005 tentang Pedoman Beracara dalam Perkara Pengujian Undang-Undang sedangkan Hak Uji Materiil (HUM) di MA ditindaklanjuti melalui Perma No 1 tahun 1993 jo Perma No. 1 Tahun 1999 jo Perma No. 1 Tahun 2004 jo Perma No. 1 Tahun 2011.

2. Problematika pelaksanaan judisial review oleh MA dan MK antara lain, Pertama, Problematika konseptual, Adanya dua lembaga yang berperan dalam judicial review maka pengawalan dan penegakkan konstitusi secara integral dan komprehensif mulai dari perda hingga UU terhadap UUD NRI 1945 akan sulit diwujudkan. Kedua, Problematika terjadinya konflik kelembagaan, perbedaan putusan dalam penafsiran undang-undangdalam kasus pemilu 2009 salah satu contoh nyata, bahwa setiap saat konflik antar kelembagaan antara MA dan MK bisa mengancam disebabkan terjadinya perbedaan penafsiran dalam menyelesaikan perkara judicial review.

\section{F. Saran}

Berdasarkan hasil penelitian dan pembahasan di atas, maka perlu dilakukan kajian lebih lanjut untuk merumuskan gagasan pengintegrasian pengujian peraturan perundang-undangan (judicial review) ke Mahkmah Konstitusi untuk memperkuat Nation Building. Kajian tersebut diantaranya seputar fungsi kekuasaan kehakiman dalam melakukan pengujian peraturan perundang-undangan (judicial review), kedudukan kelembagaan kekuasaan kehakiman, formulasi rekrutmen hakim dan manajemen peradilan. 


\section{DAFTAR PUSTAKA}

Anonim. 2004. Cetak Biru Membangun Mahkamah Konstitusi Sebagai Institusi Peradilan Konstitusi yang Modern dan Terpercaya. Jakarta: Mahkamah Konstitusi Republik Indonesia

Harjono. 2007. "Mahkamah Konstitusi dalam Sistem Ketatanegaraan Republik Indonesia". Jurnal Legislasi Indonesia, Vol. 4 No. 3 September 2007. Jakarta: Direktorat Jendral Peraturan Perundang-Undangan Departemen Hukum dan Hak Asasi Manusia RI.

Ikhsan Rosyada Parluhutan Daulay. 2006. Mahkamah Kontitusi Memahami Keberadaanya dalam Sistem Ketatanegaraan Republik Indonesia. Jakarta: PT Rineka Cipta

Iriyanto. 2008. Negara Hukum \& Hak Uji Konstitusionalitas Mahkamah Konstitusi Telaah Terhadap Kewenangan Mahkamah Konstitusi. Bandung: Alumni

Jimly Asshiddiqie. 2006. Sengketa Kewenangan Antar Lembaga Negara. Jakarta: Konstitusi Press . 2007. Konstitusi dan Ketatanegaraan Indonesia Kontemporer. Bekasi : The Biography Insti- tute . 2010. Model-Model Pengujian Konstitusional di Berbagai Negara. Jakarta: Sinar Grafika 2010. Konstitusi \& Konstitualisme Indonesia. Jakarta : Sinar Grafika

Moh. Mahfud MD. 2009. "Konstitusi Negara”. Makalah disampaikan dalam Acara Orientasi Anggota DPR RI Fraksi PDI Perjuangan 2009-2014 pada Selasa, 8 September 2009 di Ball Room Hotel Harris Tebet Jakarta.

2010. Membangun Politik Hukum Menegakkan Konstitusi. Jakarta: Rajawali Pers

Ni'matul Huda. 2008. "Urgensi Judicial Review Dalam Tata Hukum Indonesia". JURNAL HUKUM NO. 1 VOL. 15 JANUARI 2008.

Peter Mahmud Marzuki. 2007. Penelitian Hukum. Jakarta: Kencana

Zainal Arifin Hoesein. 2009. Judicial Review di Mahkamah Agung RI Tiga Dekade Pengujian Peraturan Perundang-undangan. Jakarta: Rajagrafindo Persada 